\title{
Investigations on the Phosphorus Metabolism in Rhodotorula gracilis. II. Phosphate and Phosphatide Amounts in Protein Yeast and Fat Yeast
}

\author{
N. G. NILSSON and NIELS NIELSEN
}

Division of Food Chemistry, Royal Institute of Technology, Stockholm, Sweden

\begin{abstract}
If Rhodotorula gracilis is cultivated with a sufficient amount of nitrogen, $I_{a}$ yeast containing $40-50 \%$ protein and about $10 \%$ fat is obtained. If it is cultivated in a nutrient solution with a low nitrogen content, a yeast containing $10-12 \%$ protein and $50-60 \%$ fat can be obtained. The considerable difference between the protein and fat content of these two yeast forms involves essential variations in their chemical composition ${ }^{1,2}$. In the following, the results of investigations concerning the presence of phosphorus and phosphatide in fat yeast and protein yeast from $R h$. gracilis will be presented.
\end{abstract}

\section{EXPERIMENTAL}

The yeast was cultivated in a nutrient solution with varying nitrogen content. In order to be able to make comparisons with previous experiments, the amount of phosphate and sugar in the solution was also varied. This latter variation, however, is not of any greater importance as the phosphate content in all experiments was superoptimal.

In producing the protein yeast, the following nutrient solution was used: $15 \mathrm{~g}$ asparagin - $4.7 \mathrm{~g} \mathrm{KH}_{2} \mathrm{PO}_{4}-3 \mathrm{~g} \mathrm{MgSO}_{4}, 7 \mathrm{H}_{2} \mathrm{O}-1.5 \mathrm{~g} \mathrm{NaCl}-1.5 \mathrm{~g} \mathrm{CaCl}_{2}, 6 \mathrm{H}_{2} \mathrm{O}-0.015 \mathrm{~g}$ $\mathrm{FeCl}_{3}, 6 \mathrm{H}_{2} \mathrm{O}-60 \mathrm{~g}$ glucose per litre. The $\mathrm{pH}$ of this solution was 4.8 .

In producing the fat yeast, the following solution was used: $1 \mathrm{~g}$ asparagin $-1 \mathrm{~g}$ $\mathrm{KH}_{2} \mathrm{PO}_{4}-3 \mathrm{~g} \mathrm{MgSO}_{4}, 7 \mathrm{H}_{2} \mathrm{O}-1.5 \mathrm{~g} \mathrm{NaCl}-1.5 \mathrm{~g} \mathrm{CaCl}_{2}, 6 \mathrm{H}_{2} \mathrm{O}-0.015 \mathrm{~g} \mathrm{FeCl}_{3}-40 \mathrm{~g}$ glucose per litre. pH 4.8.

The yeast was cultivated in $750 \mathrm{ml}$ Erlenmeyer flasks with $300 \mathrm{ml}$ of solution. The flasks were shaken at $25^{\circ} \mathrm{C}$.

After 72 hours the yeast was analyzed. In the analyses the dry matter, nitrogen content, fat content and phosphate content were determined. Phosphate was determined according to Fiske-Subbarow ${ }^{3}$, and the other analyses as indicated in Ref.4.

From the phosphorus content of the yeast the phosphatide content was calculated. In this calculation it was assumed that the phosphatides of the yeast contain $3.98 \%$ phosphorus which corresponds to the phosphorus content of lecithine. Even if compounds containing other percentages of phosphorus may occur in the fat, they exist in such small quantities that it is not necessary to take into consideration the slight error thereby resulting in the calculations. This method of calculation was used when the phosphatide

Acta Chem. Scand. 7 (1953) No. 7 
content was so low that a direct determination was difficult to make, $i$. e. especially in the case of the yeast containing the very high percentage of fat. In a few cases the amount of phosphatide was also determined directly, however, and the values obtained in these determinations correspond well with the results of the calculations.

\section{RESULTS}

In all experiments the yeast was cultivated (a) in solutions with a high nitrogen content, where only small amounts of fat were formed, and (b) in solutions with a low nitrogen content, where a large amount of fat was formed. Three experiments were made. The yeast was cultivated for 72 hours after which analyses were made.

In Table 1, the chemical analyses of the yeast from all the experiments are shown.

Table 1. Analyses of yeast after 72 hours.

\begin{tabular}{|c|c|c|c|c|}
\hline & Experiment & 1 & 2 & 3 \\
\hline $\begin{array}{l}\text { Fat in } \\
\text { yeast, \% }\end{array}$ & $\begin{array}{l}\text { Protein yeast } \\
\text { Fat yeast }\end{array}$ & $\begin{array}{l}11.6 \\
50.8\end{array}$ & $\begin{array}{l}12.1 \\
42.1\end{array}$ & $\begin{array}{l}12.2 \\
53.6\end{array}$ \\
\hline $\begin{array}{l}\text { Protein in } \\
\text { yeast, \% }\end{array}$ & $\begin{array}{l}\text { Protein yeast } \\
\text { Fat yeast }\end{array}$ & $\begin{array}{l}46.6 \\
12.1\end{array}$ & $\begin{array}{r}52.9 \\
19.8\end{array}$ & $\begin{array}{l}55.2 \\
14.3\end{array}$ \\
\hline$P$ in yeast, & $\begin{array}{l}\text { Protein yeast } \\
\text { Fat yeast }\end{array}$ & $\begin{array}{l}1.35 \\
0.92\end{array}$ & $\begin{array}{l}1.20 \\
0.82\end{array}$ & $\begin{array}{l}1.20 \\
0.88\end{array}$ \\
\hline $\begin{array}{r}P \text { in fat, } \\
\%\end{array}$ & $\begin{array}{l}\text { Protein yeast } \\
\text { Fat yeast }\end{array}$ & $\begin{array}{l}1.12 \\
0.16\end{array}$ & $\begin{array}{l}1.34 \\
0.18\end{array}$ & $\begin{array}{l}1.57 \\
0.11\end{array}$ \\
\hline $\begin{array}{l}\text { Phosphatide } \\
\text { in yeast, } \%\end{array}$ & $\begin{array}{l}\text { Protein yeast } \\
\text { Fat yeast }\end{array}$ & $\begin{array}{l}3.26 \\
2.04\end{array}$ & $\begin{array}{l}4.67 \\
1.90\end{array}$ & $\begin{array}{l}4.81 \\
1.48\end{array}$ \\
\hline $\begin{array}{l}\text { Phosphatide } \\
\text { in fat, } \%\end{array}$ & $\begin{array}{l}\text { Protein yeast } \\
\text { Fat yeast }\end{array}$ & $\begin{array}{r}28.11 \\
4.02\end{array}$ & $\begin{array}{r}33.63 \\
4.52\end{array}$ & $\begin{array}{r}39.41 \\
2.76\end{array}$ \\
\hline $\begin{array}{l}\text { Phosphatide N } \\
\text { in yeast }\end{array}$ & $\begin{array}{l}\text { Protein yeast } \\
\text { Fat yeast }\end{array}$ & $\begin{array}{l}0.44 \\
1.05\end{array}$ & $\begin{array}{l}0.55 \\
0.60\end{array}$ & $\begin{array}{l}0.54 \\
0.65\end{array}$ \\
\hline $\begin{array}{l}\text { Protein + fat } \\
\text { in yeast, } \%\end{array}$ & $\begin{array}{l}\text { Protein yeast } \\
\text { Fat yeast }\end{array}$ & $\begin{array}{l}58.2 \\
62.9\end{array}$ & $\begin{array}{l}65.0 \\
61.9\end{array}$ & $\begin{array}{l}67.4 \\
67.9\end{array}$ \\
\hline
\end{tabular}

As indicated by Table 1, 3 typical protein yeasts and 3 typical fat yeasts have been analyzed. In the 3 samples of protein yeast, the fat content varied between 11.6 and $12.2 \%$ and the protein content between 46.6 and $55.2 \%$. In the 3 samples of fat yeast, the fat content varied between 42.1 and $53.6 \%$ and the protein content between 12.1 and $19.8 \%$.

In the lowest section of Table 1 the sum of the fat and protein percentages in the yeast is shown. This sum is rather constant, varying only between $\mathbf{5 8 . 2}$ and $67.9 \%$ of the dry substance of the yeast. Other components thus constitute a relatively constant percentage of the yeast, $i$. e. about $35 \%$ irrespective of whether the yeast has a high fat percentage or not. 
The phosphorus content is somewhat lower in fat yeast than in protein yeast. Fat yeast contains from 0.82 to $0.92 \%$ phosphorus and protein yeast 1.20 to $1.35 \%$. There is consequently only a slight difference between fat yeast and protein yeast as far as phosphorus content is concerned.

The percentage of phosphatide (as mentioned above, calculated on the basis of the amount of phosphorus contained in the fat) is considerably lower in fat from fat yeast than in fat from protein yeast. In Table 2 the values found in the experiments to represent the phosphatide content in the fat are indicated and the yeast is listed according to fat content. In addition, the phosphatide content in percentage of the fat-free yeast substance has been calculated.

Table 2. Phosphatide content of yeast with varying fat content.

$\begin{array}{ccc}\text { Fat in yeast } & \begin{array}{c}\text { Phosphatide in fat } \\ \%\end{array} & \begin{array}{c}\text { Phosphatide in fat-free yeast } \\ \%\end{array} \\ 11.6 & & \\ 12.1 & 28.11 & 3.69 \\ 12.2 & 33.63 & 4.51 \\ 42.1 & 39.41 & 5.48 \\ 50.8 & 4.52 & 3.28 \\ 53.6 & 4.02 & 4.15 \\ & 2.76 & 3.19\end{array}$

As the figures indicate, the phosphatide content in the fat decreases considerably as the amount of fat increases. In protein yeast, the phosphatide content varies between 28.11 and $39.41 \%$, but in the case of fat yeast, it decreases in proportion to the increase of fat and is only $2.76 \%$ in the yeast with the highest fat content. In spite of this considerable variation, none of these values lie outside the limits previously established for microorganisms. For Rh. gracilis, Holmberg ${ }^{5}$ found that in one sample where the yeast contained $50 \%$ fat phosphatides constituted $3 \%$ of the fat, which is in accordance with our findings.

The phosphatide content calculated in per cent of fat-free yeast varies much less, even though the protein yeast may have a somewhat higher phosphatide content. The reason for the very slight difference in these figures is the fact that the high fat content in the fat yeast in part compensates the low percentage of phosphatide. According to Belin ${ }^{6}$ a certain amount of phosphatide is necessary for the microorganisms, and consequently it should be expected that the phosphatide content in protein yeast and fat yeast should be about the same.

The phosphatide/nitrogen relation has previously been investigated by Davidson and Leslie 7 , who found it to be relatively constant. In Table 1 this relation has been indicated for our experiments. The figures vary somewhat and tend to be slightly lower for protein yeast than for fat yeast. The variations in question, however, are rather small. 


\section{SUMMARY}

The phosphatide content in the fat is dependent to a considerable extent on the fat content of the yeast. The higher the percentage of fat in the yeast, the lower the amount of phosphatide. While fat from protein yeast contains between 30 and $40 \%$ phosphatide, fat from fat yeast only contains between 3 and 5. The lowest percentage of phosphatide is found in the yeast with the highest percentage of fat and there is a regular inverse proportion between the fat content of the yeast and the phosphatide content of the fat.

If the phosphatide content of fat-free yeast is calculated, the variations are quite insignificant, which seems to indicate that there must exist a certain amount of phosphatide in the yeast irrespective of the amount of fat in the yeast.

The phosphatide/nitrogen relation does not vary to any greater extent between protein yeast and fat yeast.

The sum of protein and fat per $\mathrm{g}$ of yeast is relatively constant, protein and fat constituting about $65 \%$ of the yeast. Thus the quantities of other substances hardly vary although the fat content may increase.

\section{REFERENCES}

1. Nielsen, N., Sandegren, E., and Ljungdahl, L. Nature 164 (1949) 1055.

2. Sandegren, E., Ekström, D., and Nielsen, N. Acta Chem. Scand. 4 (1950) 1311.

3. Fiske, C. H., and Subbarow, Y. J. Biol. Chem. 66 (1925) 375.

4. Nielsen, N., and Nilsson, N. G. Arch. Biochem. 25 (1950) 316.

5. Holmberg, J. Svensk Kem. Tidskr. 60 (1948) 14.

6. Belin, M. P. Bull. soc. chim. biol. 8 (1926) $1081,1120$.

7. Davidson, J. N., and Leslie, I. Nature 165 (1950) 49.

Received May 27, 1953. 